
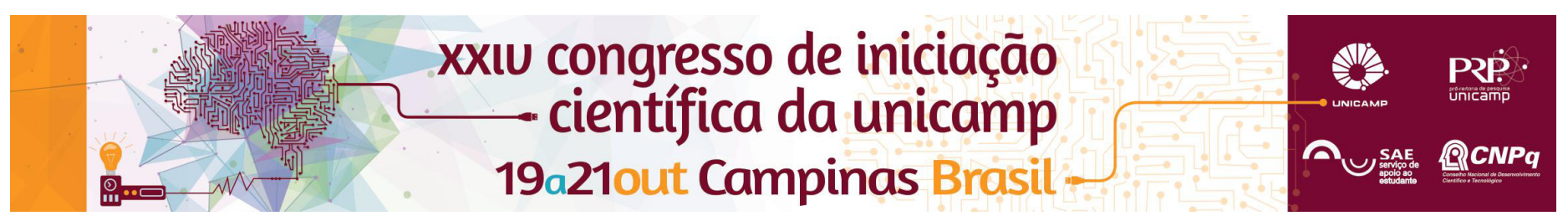

\title{
Análise numérica de pórticos de concreto armado sem armadura transversal para avaliar os mecanismos \\ resistentes \\ ao \\ cisalhamento
}

\section{José Marcelo Maizman B.*, Prof. Dr. Leandro M. Trautwein.}

\section{Resumo}

A fissuração, proveniente de esforços de tração, pode causar a ruptura do concreto e deve ser evitada para que não ocorra o colapso estrutural. $O$ trabalho experimental utilizado como referência para o desenvolvimento deste projeto consistiu no ensaio de oito pórticos de concreto armado submetidos à flexão simples. Portanto, o objetivo deste trabalho é validar os resultados experimentais de Samora (2015), sobre a parcela de força cortante resistida pelo concreto, em vigas de pórticos de concreto armado, com resultados numéricos obtidos no programa de elementos finitos Atena.

\section{Palavras-chave}

análise numérica, concreto armado, cisalhamento.

\section{Introdução}

Nas estruturas de concreto armado a sua segurança não deve depender da resistência a tração do concreto, eliminando as chances de risco de colapso sem o aviso prévio. Nas vigas de concreto armado, as primeiras fissuras que surgem (no meio do vão) são devidas aos esforços de flexão. As fissuras de cisalhamento se desenvolvem de maneira paralelas umas às outras, à medida que ocorre avanço em direção à borda comprimida. O objetivo deste trabalho é a validação dos resultados obtidos na análise numérica com os resultados experimentais obtidos por Samora (2015) avaliando a contribuição do concreto ao cisalhamento em vigas de concreto armado sem armadura transversal.

\section{Resultados e Discussão}

O pórtico analisado tanto no trabalho de Samora e introduzido no software Atena é apresentado na figura 1. Foram 8 pórticos estudados, sendo 4 pórticos diferentes (2 exemplares de cada), variando-se a resistência a compressão do concreto e a taxa de armadura.

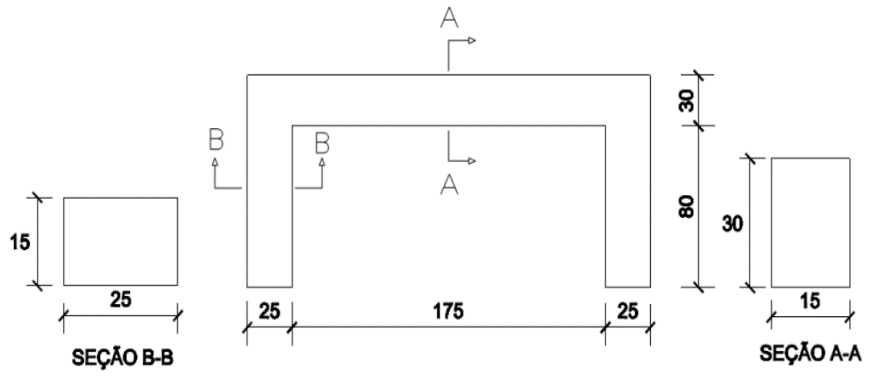

Figura 1. Características do pórtico, em $\mathrm{cm}$.

Os resultados obtidos pelo software Atena e pelo ensaio feito por Samora são representados nas figuras 2 e 3, respectivamente, para o terceiro pórtico estudado. Foi possível notar a semelhança entre os locais e disposição das fissurações nos dois casos, todos os 4 casos tiveram muita semelhança em seus resultados numéricos com os resultados experimentais. A carga de ruptura também esteve muito próxima ao valor dado pelo software, diferenciando em cerca de $5 \%$ apenas.

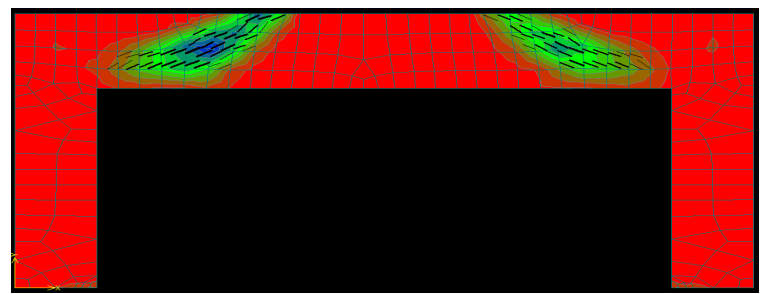

Figura 2. Fissuras apresentadas pelo software.

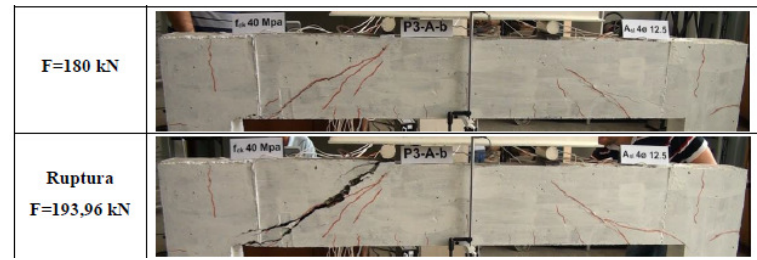

Figura 3. Fissuras no experimento.

\section{Conclusões}

O modelo estudado e analisado pelo software Atena se mostrou coerente com o trabalho realizado por Samora (2015). As fissuras se deram nas regiões apresentadas pelo software obedecendo sua angulação em relação a horizontal e as cargas de ruptura também apresentaram valores satisfatórios quando comparados àqueles obtidos no trabalho de Samora (2015). Com isso podemos confiar cada vez mais nos softwares disponibilizados hoje para facilitar o ensaio de algumas peças estruturais.

\section{Agradecimentos}

Primeiramente gostaria de agradecer ao Prof. Dr. Leandro Mouta Trautwein pela disposição, pela oportunidade que me deu e pelo seu incentivo. Ao Engenheiro Ricardo Randi pela ajuda com relação ao aprendizado do software utilizado.

1 ASSOCIAÇÃO BRASILEIRA DE NORMAS TÉCNICAS, NBR 6118. Projeto de Estruturas de Concreto Armado - Procedimento. Rio de Janeiro, 2014.

2 SAMORA, M. S.. Avaliação dos mecanismos resistentes ao cisalhamento em concreto armado sem armadura transversal. Dissertação de Mestrado. Faculdade de Engenharia Civil da Universidade Federal de Uberlândia. Uberlândia, Brasil, 2015. 